\title{
The Impact of Tourism on Economic Growth and Development in Africa
}

\author{
Bichaka Fayissa* \\ Department of Economics and Finance, Middle Tennessee State University \\ Murfreesboro, TN 37132, U. S.A., Tel (615)898-2385, Fax (615) 898-5596 \\ Email: bfayissa@mtsu.edu \\ Christian Nsiah \\ Department of Accounting and Economics, Black Hills State University \\ Spearfish, SD 57799, U.S.A., Tel (605) 642-6286 \\ Email: ChristianNsiah@bhsu.edu \\ Badassa Tadasse \\ Department of Economics, University of Minnesota-Duluth, \\ Duluth, MN-55812, U.S.A., Tel. (218) 726-8365, Fax: (218) 726-6509 \\ Email: btadesse@d.umn.edu
}

\begin{abstract}
Over the decade of the 1990s, Africa has experienced a rise in tourist arrivals from 8.4 million to 10.6 million and receipts growth from $\$ 2.3$ billion to $\$ 3.7$ billion, respectively. According to the World Tourism Organization (WTO, 2006), the tourism industry in Sub-Saharan Africa enjoyed a robust annual market share growth rate of 10 percent in 2006. In spite of this, there are only few empirical studies that investigate the contributions of tourism to economic growth and development for African economies. Using a panel data of 42 African countries for the years that span from 1995 to 2004, this study explores the potential contribution of tourism to economic growth and development within the conventional neoclassical framework. The results show that receipts from the tourism industry significantly contribute both to the current level of gross domestic product and the economic growth of Sub-Saharan African countries as do investments in physical and human capital. Our findings imply that African economies could enhance their short-run economic growth by strategically strengthening their tourism industries.
\end{abstract}

Keywords: Tourism, Economic Growth, Sub-Sahara Africa, Dynamic Panel Data, Fixed Effects, Random Effects, and Arellano-Bond Models

JEL Classifications: C33, F14, L83, O40, O54

*Bichaka Fayissa, Department of Economics and Finance, Middle Tennessee State University, Murfreesboro, TN 37132, U. S.A. Tel (615)898-2385, Fax (615) 898-5596; Email: bfayissa@ mtsu.edu 


\section{The Impact of Tourism on Economic Growth and Development in Africa}

\section{Introduction}

Worldwide, tourism grew phenomenally from 25 million arrivals in 1950 to 808 million in 2005 , with an average annual growth rate of 6.5 percent (UNWTO, 2006). In 2005, tourist arrivals in Africa registered only 37 million (or 5 percent of the world) as compared to 444 million arrivals (55 percent) in Europe, 156 million (19 percent) in Asia/ Pacific, 133 million (16 percent) in the Americas, and 38 million (5 percent) in the Middle East. In 2004, tourism receipts were $\$ 623$ billion (100\%) for the world, $\$ 326.7$ billion for Europe (52.5\%), \$131.7 billion, $\$ 21$ billion (3.4\%) for the Middle East, and $\$ 18.3$ billion (2.9\%) for Africa (See, Tables $1.1 \& 1.2)$

\section{<<Insert Tables 1.1 and 1.2 here $>>$}

While tourism generates a significant amount of foreign exchange earnings that also contribute to the economic growth of developed countries, such ingredient of growth has not been effectively harnessed in Africa. According to the World Tourism Organization (WTO, 2005) estimates, 766 million tourists who traveled world-wide in 2004 generated about $\$ 626$ billion (excluding transport). During the same year, Africa received nearly $5 \%$ of the global arrivals (or 33 million tourists), an increase over the 2000 level (28.2 million) of 18\% (Dieke, 2004). Similar increases in receipts were also registered, as reflected by the rise in the region's market share increase from $4.1 \%$ in 2000 to $4.5 \%$ in 2005 (WTO, 2006; Table 1.1). Within Africa, the northern sub-region had the highest share of tourist traffic and revenue. In rank order, the top five tourist destinations in Sub-Saharan Africa include: Seychelles, Mauritius, Namibia, Cape Verde, and Botswana (See Fig.1)

\section{$<$ Insert Figure 1 here $>>$}


The contribution of tourism to economic growth and development is reflected in the form of exports since it represents 40 percent of all exports of services, making it one of the largest categories of international trade (UNWTO, 2006). In 20005, the tourism sector accounted for 3 $\%$ to $10 \%$ of the GDP of developing countries (UNWTO, 2005). Consequently, it is not surprising to imagine that tourism can be a viable export-oriented economic growth strategy for bringing jobs and development to the people and help in the reduction of abject poverty.

Despite its increasing importance in African economies, however, tourism has attracted relatively little attention in the empirical literature on economic development. Studies examining cross-country rates of growth and development have largely focused on the contributions of exports from the agricultural and manufacturing sectors, rather than those of the service industry. Even those that explicitly examine the tourism sector in developing nations are primarily concerned with estimating and forecasting tourism demand and income generation via the multiplier process (Sinclair, 1999; Bezmen, 2006).

The main objective of this paper is to investigate the contribution of tourism to the economic growth of African economies with typically heterogeneous tourism industries using panel data of 42 African countries that span over the period 1995-2004. We also account for the traditional sources of economic growth using estimation methods that are based on simple fixed-effects and random-effects models, as well as the Arellano-Bond (2002) general method of moments (GMM) estimator. The former specifications allow us to account for the heterogeneity of African economies and the differences in the traditional sectors' contributions to the economic growth of African economies. On the other hand, the latter method allows us 
to obtain efficient and unbiased estimates of the effects of our variables of interest in the possible presence of $\mathrm{AR}(1)$ residual errors as well as the pre-determined (e.g., schooling) and endogenous (e.g., foreign direct investment) nature of some of the traditional growth factors without using an explicit instrumental variable estimation technique. The contribution of our work to the empirical literature is that we provide evidence of the extent to which the tourism industry can spur economic growth while accounting for the conventional sources of economic growth using standard theory. Our empirical results show that receipts from the tourism industry significantly contribute both to the current level of gross domestic product and the economic growth rate of Sub-Saharan African countries as do investments in physical and human capital. Our findings imply that the short-term economic growth of African economies could be spurred by strengthening their tourism industries.

The rest of the paper is organized as follows. Section 2 provides a review of selected literature. In section 3, we specify a conventional neoclassical growth model which incorporates tourism as one of the sources of growth. Section 4 presents both the fixed and random effects regression results accounting for both the country and time effects and the Arellano-Bond (2002) dynamic panel data estimates for reflecting both the dynamic nature of the data and endogeneity of some of the conventional growth sources. The last section summarizes the results, draws conclusions, and makes some policy recommendations for promoting tourism as a growth and development strategy.

\section{A Review of Selected Literature}


In a recent study of the economic growth performance of Greece, Dritsakis (2004) shows that tourism has a long-run economic growth effect. Using Spain's economic data, Balaguer and Cantavella-Jorda (2002) confirm the validity of tourism-led growth hypothesis for long-run economic performance. Oh (2005) for Korea, Tosun (1999), and Guduz and Hatemi (2005) for Turkey have also found empirical support for the tourism-led growth hypothesis. Similarly, employing the convergence approach based on Barro and Sala-i-Martin (1992a) type analysis, Proenca and Soukiazis (2005) examine the impact of tourism on the per capita income growth of Portuguese regions and draw the conclusion that tourism can be considered as an alternative solution for enhancing regional growth in Portugal, if the supply characteristics of this sector are improved. While Cunado and Garcia (2006) also find some evidence of conditional convergence toward the African regional average (for Benin, Cameroon, Cape Verde, Djibouti, Egypt, Ghana, Kenya, Mali, Uganda, and Zimbabwe) and the U.S. (for Cape Verde, Egypt, Mauritius, Seychelles, and Tunisia), the coverage given to the contribution of tourism has been scant.

Comparing the relative growth performance of 14 "tourism countries" within a sample of 143 countries, Brau, Lanza, and Pigliaru (2003) document that tourism countries grow faster than all the other sub-groups (OECD, Oil Exporting, LDC, Small). Many developing countries have thus started to consider tourism as an important and integral part of their economic growth and development strategies as it serves as a source of scarce financial resources, job creation, foreign exchange earnings, and technical assistance (Sinclair, 1998; Dieke, 2004). 
Nevertheless, Chen and Devereux (1999) argue that tourism may reduce welfare for trade regimes dominated by export taxes, or import subsidies. Using a theoretical framework, they demonstrate that foreign direct investment in the form of tourism is, for the most part, beneficial while tourist immiserization is also possible in Sub-Saharan Africa. Thus we cannot, a priori, predict the direction of the impact of tourism receipts $\left(T R P_{i t}\right)$ on the economic growth of Sub-Saharan African economies, based on the above discussions

\section{An Empirical Model of Economic Growth with Tourism}

In the economic growth literature, researchers have been interested in the rate at which countries close the gap between their current positions and their desired long-run growth path. To determine the responsiveness of income growth rate to tourism and the traditional the sources of economic growth such as investment in physical and human capital, openness of the economy as measured by the ratio of the sum of imports and exports to the GDP, often described as terms of trade, a measure of an institutional factor represented by the economic freedom index, foreign direct investment, and household consumption expenditures, we first specify a simple double log-linear Cobb-Douglass production function as:

$\ln P C I_{i t}=\beta_{0}+\beta_{1} \ln T R P_{i t}+\beta_{2} \ln G C F_{i t}+\beta_{3} \ln E F I_{i t}+\beta_{4} \ln S C H_{i t}+\beta_{5} \ln F D I_{i t}+\beta_{6} \ln T O T_{i t}+\beta_{7} \ln H H C_{i t}+\varepsilon_{i t}$

Where $\ln P C I_{i t}$ is the natural $\log$ of real GDP per capita and $T R P_{i t}$ is $\log$ of tourist receipts per capita in US\$; $G C F_{i t}$ is the log of gross fixed capital formation as a percent of real GDP used as a proxy for investment in physical capital. ${ }^{1} E F I_{i t}$ is $\log$ of a measure of the economic freedom index. Owen (1987) and Sen (1999) argue that freedom (political, economic, social, 
transparency and security) is a necessary condition for economic growth and development. Thus, we use the log of economic freedom index $\left(E F I_{i t}\right)$ to capture the effect of this institutional factor. Obtained from the Heritage Foundation (2005), economic freedom index is computed as a weighted average of fifty economic variables covering various economic, social, and governance characteristics such as stable monetary policy, market regulations and rigidities, and property rights. $E F I_{i t}$ is thus an ordinal measure ranging in value from 1 to 5 , where scores between 1.00 and 1.99 reflect 'free countries', scores of $2.00-2.99$ and 3.003.99 are classified as 'mostly free' and 'mostly unfree,' respectively. Scores between 4.00 and 5.00 describe nations categorized as "repressed economies." ${ }^{2}$ Since nations that have a lower Heritage score (higher level of freedom) have higher levels of national income, we expect the sign of the economic freedom index to be negative.

$\mathrm{SCH}_{i t}$ is log of secondary and tertiary school enrollment used as measure of investment in human capital; $F D I_{i t}$ is the $\log$ of foreign direct investment to capture the effect of external sources of investment on growth; and $T O T_{i t}$ is the log of terms of trade for each country under consideration, measured by the ratio of the export to import prices indices (See, Table 1.3 for detailed definitions) to capture the impact of trade, or openness of the economy on economic growth.

\section{<<Insert Table 1.3 here $>>$}

Investment in physical capital $\left(G C F_{i t}\right)$ and human capital $\left(S C H_{i t}\right)$, a measure of the openness of the economy $\left(T O T_{t}\right)$, and foreign direct investment $\left(F D I_{i}\right)$ account for the conventional sources of economic growth. We hypothesize a positive relation between investment in physical capital $\left(G C F_{i t}\right)$, investment in human capital $\left(S C H_{i t}\right)$, the openness of the economy $\left(T O T_{i t}\right)$, and per 
capita income levels $\left(P C I_{i t}\right)$. Since the effect of foreign direct investment $\left(F D I_{i t}\right)$ on economic growth has been mixed, the expected relation may be positive, or negative.

The impact of household consumption expenditures $\left(H H C_{i t}\right)$ on economic growth is controversial. Neoclassical economic theory posits (Solow, 1956; Kuznets, 1966; Todaro, 2005) that higher household consumption expenditures tend to lower economic growth by lowering investment because of reduced savings. On the other hand, Myrdal (1969) has argued that increased household expenditures on health, nutrition, and education are actually economic growth-enhancing rather than growth-retarding, as healthy and educated households are more productive, contributing to economic growth. In a recent study, Ranis (2004) argues that individual and household consumption can be important in increasing human development and may respond more closely with the real needs of the population than do government programs at the micro level. Individual consumption may not, however, always go towards goods which maximally contribute to human development through income growth. Consequently, the effect of household consumption expenditures $\left(H H C_{i t}\right)$ on economic growth cannot be determined $a$ priori.

To estimate the parameters corresponding to variables of interest from the data under consideration, we employ a panel data estimation, an empirical exposition of which is provided in equation (2) below.

$$
Y_{i t}=\delta_{i}+\Gamma_{t}+\left(\mathrm{X}_{i t}\right) \Phi+\psi_{i t}
$$


where $Y_{i t}$ is the natural logarithm of real GDP per capita in country $i$ at year $t$, and $\mathrm{X}_{i t}$ is a vector of the explanatory variables (tourism receipts per capita, investment in physical and human capital, openness, economic freedom index, and household consumption expenditures) for country $\mathrm{i}=1,2 \ldots, \mathrm{m}$ and at time $\mathrm{t}=1,2, \ldots, \mathrm{T}, \Phi$ a scalar vector of parameters of $\beta_{1} \ldots, \beta_{7}$; $\psi_{i t}$ is a classical stochastic disturbance term with $\mathrm{E}\left[\psi_{i t}\right]=0$ and $\operatorname{var}\left[\psi_{i t}\right]=\sigma_{\dot{\varepsilon}}{ }^{2}, \delta_{\mathrm{i}}$ and $\Gamma_{t}$ are country and time specific effects, respectively. Instead of a priori decision on the behavior of $\delta_{\mathrm{i}}+\Gamma_{\mathrm{t}}$, different types of assumptions are separately imposed on the model and the one that gives robust estimates is chosen.

If we assume the country specific effects to be constant across countries and the time specific effects are not present [i.e. $\delta_{\mathrm{i}}=\lambda$ and $\left.\Gamma_{t}=0\right)$ ], then model (2) is estimated by the Ordinary Least Squares (OLS) method, or restricted OLS method. The second estimation technique assumes that the country specific effects are constant, but not equal (i.e. $\delta_{\mathrm{i}}=\lambda_{i}$ and $\Gamma_{t}=0$ which yields a one-way fixed effects model. The third assumption is a situation where the country effects are not constants, but rather are disturbances; the time effects are not present [i.e. $\delta_{i}=\lambda$ $+\mathrm{w}_{\mathrm{i}}$ and $\left.\Gamma_{t}=0\right]$ where $\mathrm{E}\left[\mathrm{w}_{i}\right]=0$ and $\operatorname{var}\left[\mathrm{w}_{i}\right]=\sigma_{\mathrm{w}}{ }^{2}$ and $\operatorname{cov}\left[\psi_{i}, \mathrm{w}_{i}\right]=0$. In this case, model (2) is estimated by the generalized least squares (GLS) which yields random-effects model.

Given that some of the traditional growth explaining factors are either pre-determined, or endogenous, or both, and current period growth could depend on its values in the past, a dynamic variant of the fixed and random effects provided in Equation (2) above, known as the Arellano-Bond estimation (1991) is specified as follows: 


$$
\Delta Y_{i t}=\alpha^{\prime} \Delta Y_{i t-1}+\beta^{\prime} \Delta X_{i t-1}+\gamma^{\prime} Z_{i t}+v_{i}+\varepsilon_{i t}
$$

where $\Delta Y_{i t}$ is first difference of the natural log of per capita income growth in country $i$ during time $t ; \Delta Y_{i t-1}$ is lagged difference of the dependent variable, $\Delta X_{i t-1}$ is a vector of lagged level and differenced predetermined and endogenous variables, $z_{i t}$ is a vector of exogenous variables, and $\alpha, \beta$, and $\gamma$ are parameters to be estimated. $v_{i}$ and $\varepsilon_{\mathrm{it}}$ are assumed to be independent over all time periods in country $i$. The term $v_{i}$ represents country specific effects which are independently and identically distributed over the countries while $\varepsilon_{i t}$ noise stochastic disturbance term and is also assumed to be independently distributed. We derive the coefficients using the Arellano-Bond (1991) Generalized Method of Moments (GMM) estimator to evaluate the joint effects of tourism receipts and the other explanatory variables on the economic growth of African countries while controlling for the potential bias due to the endogeneity of some of the regressors. All data, except for the economic freedom index which is taken from the Heritage Foundation, are from the World Bank Development Indicators (WDI, 2006) CDROM. The definitions and descriptive statistics of each variable included in the model are provided in Table 1.3.

\section{Empirical Results and Interpretations}

We start the discussion of our findings based on the fixed-effects and random-effects results reported in Tables 2. Broadly, the results of both models reveal the expected relationship between the GDP per capita income $\left(P C I_{i t}\right)$ and the explanatory variables. In both models, the variables representing the sources of growth have the expected signs. Because we estimated a double-logarithmic model, all the coefficients represent elasticities. 


\section{$<$ Insert Table 2 here $>>$}

Comparison of the consistent fixed-effects model with the efficient random-effects model using the Hausman specification test, reject the random effects in favor of the fixed effects estimates at $p<0.05$. The results from our model of choice indicate that tourism $(T R P)$ has a positive and statistically significant effect on the GDP per capita (at $p<.01$ ) of African countries. Accordingly, we find that a 10 percent increase in the tourism receipts of a typical African economy would result in a 0.3 percent increase in the average per capita income. Similarly, a 10 percent increase in investment in human capital $(S C H)$ through increases in secondary and tertiary levels school enrollment will increase GDP per capita by 0.6 percent. Consistent with the findings of Barro (1990), Sinclair (1998), Temple (1999), Dritsakis (2004), and Durbarry (2004), we also find that investment in physical capital (GCF) as measured by the gross fixed capital formation as a percent of GDP and household per capita consumption expenditures $(H H C)$ have a positive and statistically significant impact on the real GDP of the sample African economies i.e., we observe that a 10 percent increase in the household per capita consumption expenditures will lead to a 3.51 percent increase in the GDP per capita of a typical African economy, a huge impact relative to the other sources of growth.

Foreign direct investment $(F D I)$ and the terms of trade $(T O T)$ have a positive impact on the real GDP growth rate, but are not statistically significant. On the other hand, the institutional variable $(E F I)$ used to capture the effect of economic and political freedom shows that poor governance is an important bottleneck to the observed economic growth performances of African economies. Consistent with arguments made by Sen (1990) and Owen (1987), our 
estimates indicate that a one percentage point improvement (a reduction in the index of economic freedom) would lead to an almost 0.11 percent improvement in GDP per capita of a typical African economy.

While results based on the fixed and random effects models in which we simultaneously account for the heterogeneity and time to time fluctuations in the economic performance of African economies are appealing, we note that several of the traditional growth explanatory variables we include in the regression either pre-determined or endogenous, thus confounding the results. For example, while FDI and investment in human capital $(\mathrm{SCH})$ have often been credited for their role in the economic growth of a country, there is also ample evidence (Hansen and Rand, 2006; de Mello, 1999) that the level of GDP and its growth rate have feedback effects on the amount of FDI a country receives, and the rate of investment in human capital formation. Given that we are mainly interested in analyzing the effect of tourism receipts on African economic growth while accounting for the traditional growth explanatory factors that are either pre-determined (e.g., schooling) or endogenous (e.g., FDI), or both, we employ the Arellano-Bond dynamic panel General Method of Moments (GMM) estimator to obtain robust estimates. One period lagged levels and first difference of the variables serve as instruments for the endogenous variables. The Arellano-Bond dynamic GMM estimates are reported in Table 3.

\section{< Insert Table 3 here $>>$}

Column 2 reports results based on one lag and Column 3 reports results that incorporate two lags of the dependent variable (growth in GDP per capita). In both models, the Sargan test 
fails to reject the null hypothesis that the over-identifying restrictions are valid. While the Arellano-Bond test rejects the null hypothesis of no-first autocorrelation in the differenced residuals $\mathrm{AR}(1)$, it fails to reject the null hypothesis of no second order autocorrelation in the differenced residuals. ${ }^{3}$ Consequently, the estimated coefficients reflect the true (efficient and unbiased) relationship between growth in African per capita GDP and tourism (our variable of interests) and the traditional growth determinants that are either pre-determined, or endogenous, or both.

Based on the results from the model, we observe that the lagged values of GDP per capita $(P C I)$ and changes in tourism receipts $(T R P)$ have a significant and positive impact on the per capita income growth rate of African economies. Accordingly, a 10 percent increase in tourism receipts would lead to a 0.25 percent growth in the GDP pre capita of African economies. Accounting for the endogenous nature of the traditional growth explaining factors, we find that while foreign direct investment $(F D I)$, the terms of trade $(T O T)$, and the institutional variable proxied by the economic freedom index $(E F I)$ were not significant, investment in physical $(G C F)$, and human capital $(S C H)$, household per capita expenditures $(H H C)$ have significant growth enhancing roles.

\section{Conclusion}

The main goal of this study is to investigate the effect of international tourism on the economic growth and development of Sub-Saharan African countries. The results show that the spending of international tourists positively impacts the economic growth of African countries. We have found that a 10 percent increase in the spending of international tourists leads to a 0.4 percent 
increase in the GDP per capita income. According to the World Tourism Organization (WTO), Sub-Saharan Africa offers a considerable potential, not only for seaside tourism, but also for environmental and ecotourism, cultural tourism, sports tourism, and discovery tourism. However, this potential remains largely untapped.

In addition, the results show that the conventional sources of growth such as investment in physical and human capital and the ability of households to have the wherewithal of spending on health, housing, nutrition, and other household items can enhance their productivity and spur their economic growth. A policy implication which may be drawn from this study is that African countries can improve their economic growth performance, not only by investing on the traditional sources of growth such as investment in physical and human capital, trade, and foreign direct investment, but also by strategically harnessing the contribution the tourism industry and improving their governance performance. 


\section{References}

Arellano, M. and S. Bond, 1991, "Some Tests of Specification for Panel Data: Monte Carlo Evidence and an Application to Employment Equations," Review of Economic Studies, 58, 277-297.

Arellano, M. and S. Bond, 2002, Panel Data Estimation using DPD for Ox, Oxford, Nuffield College.

Balaguer, J. and M. Cantavell-Jorda, 2002, “Tourism as a Long-run Growth Factor: The Spanish Case,” Applied Economics, 34, No. 7 (May 202): 877-884.

Barro, R.J., 1990, “Government Spending in a Simple Model of Endogenous Growth,” Journal of Political Economy, 98:.S103-25.

Barro, R. J. and X. Sala-i-Martin, 1992a, "Convergence," Journal of Political Economy, 110: 223-251.

Barro, R.J. and X. Sala-i-Martin, 1992b, "Public Finance in Models of Economic Growth," Review of Economic Studies, 54:646-61.

Behabib, J. and M. Spiegel, 1994, "The Role of Human Capital in Economic Development: Evidence from Aggregate Country Cross-Data," Journal Monetary Economics, 34:143173.

Bezmen, Trisha, "Estimating the Impact of Tourism on Economic Development in Latin America," Paper presented at the Academy of Economics and Finance, Houston, TX, February 8-11, 2006.

Brau, R., A. Lanza, and F. Pigliaru, 2003, "How fast ar the Tourism Countries Growing? The Corss-Country Evidence,"CRENoS Centro Ricerche Economiche Nord Sud, working Paper, N0O3-09, http://www.crenos.it/working/pdf/03-09.pdf

Burr, Deborah. 1994. "A Comparison of Certain Bootstrap Confidence Intervals in the Cox Model." Journal of the American Statistical Association, 89(428): 1290-1302.

Chen, L. L. and J Devereux, 1999, "Tourism and welfare in Sub-Saharan Africa: a Theoretical Analysis," Journal of African Economies, 8:209-227.

Choe, J. I., 2003, “Do Foreign Direct Investment and Gross Domestic Investment Promote Economics Growth?” Review of Development Economics, 7 (1):44-57.

Cunado, J. and F. Perez de Garcia, 2006, "Real Convergence in Africa in the second-half of the $20^{\text {th }}$ century," Journal of Economics and Business, 58 (2006): 153-167. 
de Mello, L. R., 1999, "Foreign Direct Investment-led Growth: Evidence from Time Series Panel Data," Oxford Economic Papers, 51 (1)"133-151.

Dieke, Peter U.C., 2004, "Tourism in Africa's Economic Development: Policy Implication," Management Decision, 41 (3):287-295.

Dritsakis, Nikolas, 2004, "Tourism as a Long-run Economic Growth Factor: An Empirical Investigation for Greece,” Tourism Economics, 10 (3), (September 2004):305-316.

Durbarry, R., 2004, "Tourism and Economic Growth: The Case of Mauritius," Tourism Economics, 10, (3): 389-401.

Eugenio-Martin, Juan Luis, Noelia Martin Morales, and Riccardo Scarpa, 2004, "Tourism and Economic Growth in Latin American Countries: A Panel Data Approach," FEEM Working Paper No. 26.2004.

Greene, William H., 2000, Econometric Analysis, $4^{\text {th }}$ edition, Prentice Hall.

Grossman, Gene M. and Elhanan Helpman,1991, Innovation and Growth in the Global Economy, MIT Press, Cambridge, MA.

Gunduz, Lokman and Abdulnasser Hatemi, 2005, "Is the tourism-led growth hypothesis valid for Turkey?" Applied Economics,(12): 499-504.

Hansen, H. and J. Rand, 2006, "On the Causal Links between FDI and Growth in Developing Countries," http://www.blackwell-synergy.com/doi/pdf/10.1111/j.1467$\underline{\text { 9701.2006.00756.x }}$

Heritage Foundation, 2005, Index of Economic Freedom ( available at http://www.heritage.org/research/features/index/scores.cfm.)

Lucas, R.E. Jr., 1988, “On the Mechanics of Economic Growth,” Journal of Monetary Economics, (22):3-42.

Kuznets, S., 1966, Modern Economic Growth (New Haven, CT: Yale University Press).

Mudambi, R.,1994, “A Ricardian Excursion to Bermuda: An Estimation of Mixed Strategy Equilibrium," Applied Economics, (26):927-936.

Myrdal, G., 1968, Asian Drama: An Inquiry into the Poverty of Nations, New York, Pantheon Books

Nude, W.A. and A. Saayman, 2004, "The Determinants of Tourist Arrivals, in Africa: A Panel Data Regression Analysis," Paper prepared for the International Conference, Centre for the Study of African Economies, St. Catherine's College, University of Oxford, 21-22, March 2004. 
Oh, C., 2005, "The Contribution of Tourism Development to Economic Growth in the Korean Economy, Tourism Management, 26 (1):39-44.

Owen Edgar, 1987, The Future of Freedom in the Developing World, Pergamon Press.

Proenca, Sara and Elias Soukiazis, 2005, "Tourism as an Alternative Source of Regional Growth in Portugal,"Centro de Estudos da Uniao Europeia Faculdade de Economia da Unversidade de Coimbra, Discussion paper No 34 http://www4.fe.uc.pt/ceue/working_papers/ieliassara34.pdf.

Ranis, G. 2004, Human Development and Economic Growth, Economic Growth Center, Yale University, Center Discussion Paper, NO. 887.

Sen, A.N., 1999, Development as Freedom, New York: Alfred A. Knopf.

Sinclair, M.T., 1998, “Tourism and Economic Development: A Survey,” Journal of Development Studies, 34 (5): 1-51.

Solow, R., 1956, "A Contribution to the Theory of Economic Growth," Quarterly Journal of Economics, 70:65-94.

Todaro, M., 2005, Economic Development, $9^{\text {th }}$ Edition, Addison-Wesley Publishers.

Tosun, C., 1999, "An Analysis of Contributions International Inbound tourism to the Turkish Economy," Tourism Economics, 5:217-250.

UNCTAD, 2005, Handbook of Statistics, (http://www.unctad.org)

UNDP, 2005, Human Development Report, New York: United Nations Development Programme.

UNWTO, 2006, “Africa: A Key Resource for Economic and Social Development,” Global Envision, October 16, 2006.

White, H., 1980, “A Heteroscedasticity-Consistent Covariance Matrix Estimator and a Direct Test for Heteroscedasticity," Econometrica, 48:817-838.

World Bank. (2005) World Development Indicators 2005, Washington, DC: World Bank.

World Trade Organization (WTO), Annual Report, 2002.

World Tourism Organization (UNWTO) 2005, Tourism Market Trends, November 2005.

World Tourism Organization (WTO): http://www.world-tourism.org/regional/africa/ programme/specific_programme.htm 
Table 1.1: International Tourist Arrivals and Market Share by Regions

\begin{tabular}{lllllllll}
\hline Regions & 2000 & 2001 & 2002 & 2003 & 2004 & 2005 & $\begin{array}{l}\text { Share(\%) } \\
(2000)\end{array}$ & $\begin{array}{l}\text { Share(\%) } \\
(2005)\end{array}$ \\
\hline World & 689 & 688 & 709 & 697 & 766 & 808 & 100 & 100 \\
Europe & 396.2 & 395.8 & 407.4 & 408.6 & 425.6 & 443.9 & 57.5 & 54.9 \\
Mid/East & 140.8 & 143.7 & 147.6 & 147.7 & 149.5 & 158.8 & 20.4 & 19.8 \\
Asia/Pacific & 111.4 & 116.6 & 126.1 & 114.2 & 145.4 & 156.2 & 16.2 & 19.3 \\
Americas & 128.2 & 122.2 & 116.7 & 113.1 & 125.8 & 133.1 & 18.6 & 16.5 \\
Africa & 28.2 & 28.9 & 29.5 & 30.7 & 33.3 & 36.7 & 4.1 & 4.5 \\
North-Africa & 10.2 & 10.7 & 10.4 & 11.1 & 12.8 & 13.6 & 1.5 & 1.7 \\
\hline Sub-Saharan Africa & 18 & 18.2 & 19.1 & 19.6 & 20.5 & 23.1 & 2.6 & 2.9 \\
\hline
\end{tabular}

Source: World Tourism Organization, January 2006.

Table 1.2: International Tourism Receipts by Regions of the World

\begin{tabular}{lllll}
\hline & 2003 (US\$bill.) & 2004 (US\$bill. & Share (\%) & $\begin{array}{l}\text { Receipts/ Arrival- } \\
2004\end{array}$ \\
\hline World & 524 & 626 & $100 \%$ & 820 \\
Europe & 282.7 & 326.7 & 52.5 & 780 \\
Americas & 114.1 & 131.7 & 21.1 & 1.050 \\
Asia/ Pacific & 94.9 & 125 & 20.1 & 820 \\
Middle East & 16.8 & 21.0 & 3.4 & 590 \\
\hline Africa & 15.5 & 18.3 & 2.9 & 550 \\
\hline
\end{tabular}

Source: UNWTO, 2005.

Figure 1: Top Five Sub-Saharan African Countries, International Tourist Receipts Per Capita

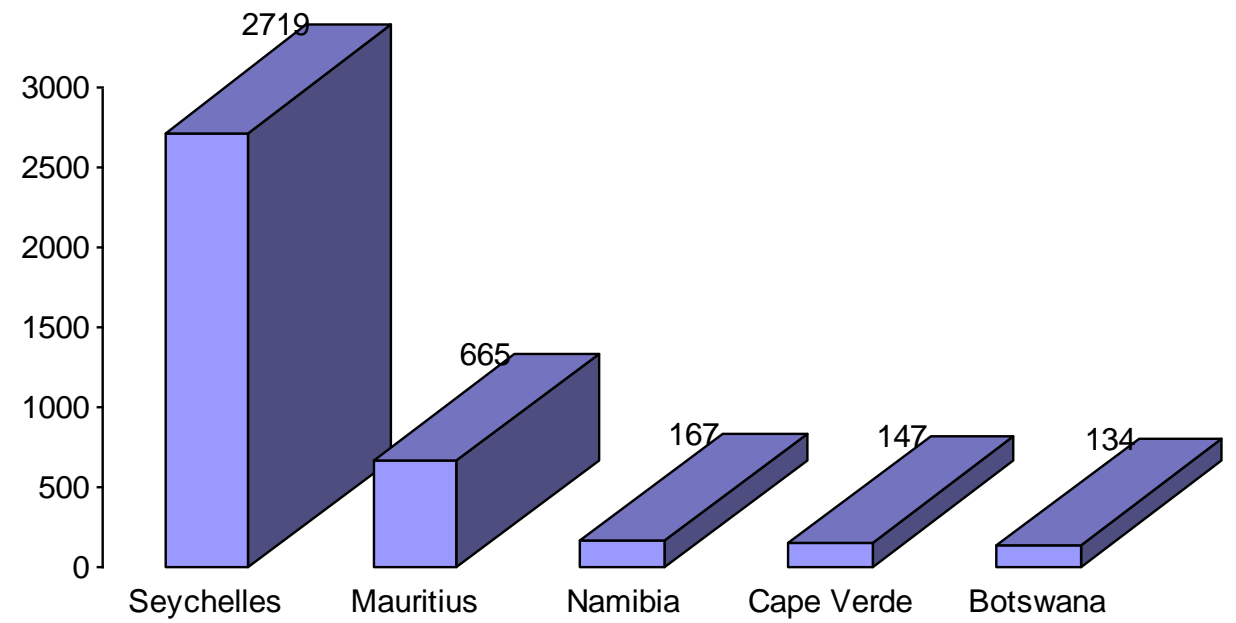


Table 1.3: Variable Description and Summary Statistics

\begin{tabular}{|c|c|c|c|c|c|}
\hline Variable & Description & Obs. & Mean(Std. Dev) & Minimum & Maximum \\
\hline$P C I$ & $\begin{array}{l}\text { GDP per capita (constant } 2000 \text { US\$) } \\
\text { International tourism, receipts (current US\$) }\end{array}$ & 240 & $2.658(0.483)$ & 1.763 & 3.874 \\
\hline TRP & Per Capita & 170 & $1.051(-0.786)$ & -0.768 & 3.490 \\
\hline$G C F$ & Gross fixed capital formation ( $\%$ of GDP) & 192 & $8.629(0.669)$ & 5.377 & 10.417 \\
\hline$E F I$ & Economic Freedom Index & 225 & $0.554(0.069)$ & 0.349 & 0.695 \\
\hline $\mathrm{SCH}$ & $\begin{array}{l}\text { log School enrollment, secondary }+ \text { tertiary } \\
\text { (\% gross) } \\
\text { Foreign direct investment, net inflows }(\% \text { of }\end{array}$ & 240 & $1.441(0.309)$ & 0.767 & 2.204 \\
\hline FDI & GDP) & 230 & $0.172(0.756)$ & -4.964 & 2.025 \\
\hline TOT & Net barter terms of trade $(2000=100)$ & 226 & $1.990(0.098)$ & 1.430 & 2.255 \\
\hline$H H C$ & $\begin{array}{l}\text { Household final consumption expenditure } \\
\text { per capita (constant } 2000 \text { US\$) }\end{array}$ & 240 & $568.66(816.4)$ & 67.1 & 4809 \\
\hline
\end{tabular}

Note: Number of countries $=48$, the values of the variables used are two year averages from 1995 through 2004 (5 year biannual panel); All variables are log transformed. All data are from World Banks, World Development Indicators CDROM. 
Table 2: Fixed Effects and Random Effects Estimates

\begin{tabular}{|c|c|c|c|}
\hline Variable & Description & $\begin{array}{c}\text { Fixed-Effects } \\
\text { Coefficients }\end{array}$ & $\begin{array}{c}\text { Random- Effects } \\
\text { Coefficients }\end{array}$ \\
\hline$T R P$ & $\begin{array}{l}\text { International tourism, receipts (current US\$) } \\
\text { Per Capita }\end{array}$ & $\begin{array}{c}0.0378 * * * \\
(0.0085) \\
0.0337\end{array}$ & $\begin{array}{c}0.0388 * * * \\
(0.010) \\
0.0402 *\end{array}$ \\
\hline$G C F$ & Gross fixed capital formation ( $\%$ of GDP) & $\begin{array}{c}(0.018) \\
-0.111^{*}\end{array}$ & $\begin{array}{c}(0.022) \\
-0.158 * *\end{array}$ \\
\hline$E F I$ & Economic Freedom Index & $(0.065)$ & $(0.078)$ \\
\hline $\mathrm{SCH}$ & $\begin{array}{l}\text { School enrollment, secondary }+ \text { tertiary }(\% \\
\text { gross) } \\
\text { Foreign direct investment, net inflows }(\% \text { of }\end{array}$ & $\begin{array}{c}0.0568 * * * \\
(0.014) \\
0.00354\end{array}$ & $\begin{array}{c}0.0566 * * * \\
(0.017) \\
0.00243\end{array}$ \\
\hline$F D I$ & GDP) & $\begin{array}{c}(0.0035) \\
0.0262\end{array}$ & $\begin{array}{c}(0.0042) \\
0.0248\end{array}$ \\
\hline TOT & Net barter terms of trade $(2000=100)$ & $(0.022)$ & $(0.026)$ \\
\hline$H H C$ & $\begin{array}{l}\text { Household final consumption expenditure per } \\
\text { capita (constant } 2000 \text { US\$) }\end{array}$ & $\begin{array}{l}0.317 * * * \\
(0.033)\end{array}$ & $\begin{array}{l}0.459 * * * \\
(.036)\end{array}$ \\
\hline Constant & Intercept & $\begin{array}{c}3.879 * * * \\
(0.23)\end{array}$ & $\begin{array}{l}3.083 * * * \\
(0.027)\end{array}$ \\
\hline Observations & & 224 & 224 \\
\hline$R$-Squared & & .57 & \\
\hline
\end{tabular}

Standard errors in parentheses; $* * * p<0.01, * * \mathrm{p}<0.05, * \mathrm{p}<0.1$. All Variables are log Transformed 
Table-3: Arellano-Bond Dynamic Panel-Data Estimation-Results

\begin{tabular}{|c|c|c|}
\hline Variables & $\begin{array}{c}\text { (1) } \\
\text { Coefficient Estimates } \\
\text { (One-Step and One-Year Lag) }\end{array}$ & $\begin{array}{c}\text { (2) } \\
\text { Coefficient Estimates } \\
\text { (One-Step and Two-Years Lag) }\end{array}$ \\
\hline PCI (LD) & $\begin{array}{c}0.568 * * * \\
(0.073)\end{array}$ & $\begin{array}{c}0.366^{* * * *} \\
(0.100)\end{array}$ \\
\hline PCI (L2D) & & $\begin{array}{c}0.234 * * * \\
(0.072)\end{array}$ \\
\hline $\operatorname{TRP}(\mathrm{D}(1))$ & $\begin{array}{l}0.0249 * * * \\
(0.0081)\end{array}$ & $\begin{array}{l}0.0256^{* * *} \\
(0.0081)\end{array}$ \\
\hline GCF (D(1)) & $\begin{array}{l}0.0290 * \\
(0.017)\end{array}$ & $\begin{array}{c}0.0404 * * \\
(0.017)\end{array}$ \\
\hline EFI $(D(1))$ & $\begin{array}{l}-0.0716 \\
(0.058)\end{array}$ & $\begin{array}{l}-0.0586 \\
(0.058)\end{array}$ \\
\hline $\mathrm{SCH}(\mathrm{D}(1))$ & $\begin{array}{l}0.0137 * \\
(0.0014)\end{array}$ & $\begin{array}{l}0.0206 * * \\
(0.0014)\end{array}$ \\
\hline $\mathrm{SCH}(\mathrm{LD})$ & $\begin{array}{c}-0.00231 \\
(0.012)\end{array}$ & $\begin{array}{c}-0.00123 \\
(0.022)\end{array}$ \\
\hline FDI $(D(1))$ & $\begin{array}{l}-0.00144 \\
(0.0023)\end{array}$ & $\begin{array}{c}-0.000622 \\
(0.0022)\end{array}$ \\
\hline FDI (LD) & $\begin{array}{c}0.0012 \\
(0.0054)\end{array}$ & $\begin{array}{c}0.0022 \\
(0.0072)\end{array}$ \\
\hline TOT (D(1)) & $\begin{array}{r}-0.0100 \\
(0.016)\end{array}$ & $\begin{array}{l}-0.0116 \\
(0.015)\end{array}$ \\
\hline $\mathrm{HHC}(\mathrm{D}(1))$ & $\begin{array}{c}0.202 * * * \\
(0.029)\end{array}$ & $\begin{array}{l}0.239 * * * \\
(0.028)\end{array}$ \\
\hline Constant & $\begin{array}{c}0.000610 \\
(0.0016)\end{array}$ & $\begin{array}{c}-0.0000863 \\
(0.0017)\end{array}$ \\
\hline Number of Observations & 165 & 144 \\
\hline Number of Countries & 30 & 30 \\
\hline Wald Chi-Square & $185.5 * * *$ & $222.3 * * *$ \\
\hline Degrees of Freedom & 10 & 11 \\
\hline $\begin{array}{l}\text { Arellano-Bond Test of the null of No AR(1) } \\
\text { Residual Errors }\end{array}$ & $\begin{array}{l}-3.93 * * * \\
(0.0001)\end{array}$ & $\begin{array}{l}-2.37 * * \\
(0.0178)\end{array}$ \\
\hline $\begin{array}{l}\text { Arellano-Bond test of the null of No AR(2) } \\
\text { Residual Errors }\end{array}$ & $\begin{array}{c}0.86 \\
(0.3890)\end{array}$ & $\begin{array}{c}-1.2 \\
(0.229)\end{array}$ \\
\hline $\begin{array}{l}\text { Sargan Test of the Validity of the null of over- } \\
\text { identifying Restrictions }\end{array}$ & $\begin{array}{c}47.09 \\
(0.183)\end{array}$ & $\begin{array}{c}40.11 \\
(0.184)\end{array}$ \\
\hline
\end{tabular}

Standard Errors In Parenthesis; ***, **, and * indicate significance at $\mathrm{p}<0.01, \mathrm{p}<0.05$, and $\mathrm{p}<0.1$ levels, respectively. While the suffix $\mathrm{D}(1)$ after each variable denotes the number of times the specific variable was differenced. LD denotes the lagged difference. The variable $\mathrm{SCH}$ is treated as pre-Determined, while FDI is treated as an endogenous variable 


\section{End Notes}

${ }^{1}$ Our specification in $\mathrm{Eq}(1)$ is based on the empirics in the new growth theory (Lucas, 1988; Barro, 1990; Benhabib and Spiegel, 1994; Grossman and Helpman, 1991; Barro and Sala-i-Martin, 1992b; Barro and Lee, 1994; and Temple, 1999).

${ }^{2}$ The sample average of economic freedom for the countries in the sample is 3.67, with the lowest being 2.29 in Botswana and the greatest being 4.23 in Zimbabwe.

${ }^{3}$ In a separate specification, not reported here, we also estimate the Arellano-Bond dynamic panel data model by including year dummies to capture the effect of time trend. The results do not differ. 